\title{
Enhanced heterologous production of eicosapentaenoic acid in Escherichia coli cells that co-express eicosapentaenoic acid biosynthesis $p f a$ genes and foreign DNA fragments including a high-performance catalase gene, vktA
}

\author{
Yoshitake Orikasa - Yukiya Ito - Takanori Nishida - Kazuo Watanabe · \\ Naoki Morita $\cdot$ Takuji Ohwada $\cdot$ Isao Yumoto $\cdot$ Hidetoshi Okuyama
}

Published online: 17 March 2007

(C) Springer Science+Business Media B.V. 2007

\section{Erratum to: Biotechnol Lett \\ DOI 10.1007/s10529-007-9310-0}

There were typing errors in Tables 1 and 2 of the original. The corrected Tables plus an updated reference are shown on the following page.

The online version of the original article can be found at http://dx.doi.org/10.1007/s10529-007-9310-0

Y. Orikasa · T. Nishida $\cdot$ H. Okuyama $(\bowtie)$

Graduate School of Environmental Earth Science,

Hokkaido University, Kita-ku, Sapporo 060-0810,

Japan

e-mail: hoku@ees.hokudai.ac.jp

Y. Ito

ROM Co. Ltd., Chuo-ku, Sapporo 064-0804, Japan

K. Watanabe

Sagami Chemical Research Center, Hayakawa, Ayase

252-1193, Japan

N. Morita $\cdot$ I. Yumoto

Research Institute of Genome-based Biofactory,

National Institute of Advanced Industrial Science and

Technology (AIST), Sapporo 062-8517, Japan

T. Ohwada

Department of Agricultural and Life Sciences,

Obihiro University of Agriculture and Veterinary

Medicine, Inada-cho, Obihiro 080-8555, Japan 
Table 1 Fatty acid composition of E. coli DH5 $\alpha$ and its various transformants and recovered amount of EPA from cultures

\begin{tabular}{|c|c|c|c|c|c|c|}
\hline \multirow[t]{2}{*}{ Strains $^{\mathrm{a}}$} & \multicolumn{5}{|c|}{ Fatty acid $^{\mathrm{b}}(\%$ total $)$} & \multirow{2}{*}{$\begin{array}{l}\text { Content of EPA } \\
\left(\mu \mathrm{g} \mathrm{ml} l^{-1}\right)\end{array}$} \\
\hline & $16: 0$ & 16:1(9) & $18: 1(11)$ & EPA & Others $^{\mathrm{c}}$ & \\
\hline E. coli $\mathrm{DH} 5 \alpha$ & $36.0 \pm 1.0$ & $29.6 \pm 0.7$ & $22.0 \pm 0.6$ & 0 & $12.5 \pm 1.4$ & 0 \\
\hline E. coli $\mathrm{DH} 5 \alpha(\mathrm{pEPA} \Delta 1)$ & $35.6 \pm 0.9$ & $26.9 \pm 1.5$ & $21.8 \pm 0.9$ & $2.5 \pm 0.2$ & $13.2 \pm 2.7$ & $1.7 \pm 0.1$ \\
\hline E. coli $\mathrm{DH} 5 \alpha(\mathrm{pEPA} \Delta 1)(\mathrm{pGBM} 3)$ & $38.6 \pm 1.8$ & $28.2 \pm 0.6$ & $20.8 \pm 0.3$ & $3.2 \pm 1.7$ & $9.2 \pm 1.1$ & $1.5 \pm 1.3$ \\
\hline E. coli $\mathrm{DH} 5 \alpha(\mathrm{pEPA} \Delta 1)[\mathrm{pGBM} 3:: \mathrm{sal}(v k t A)]$ & $35.9 \pm 3.1$ & $18.5 \pm 0.4$ & $22.9 \pm 1.9$ & $12.3 \pm 0.7$ & $10.3 \pm 0.8$ & $7.3 \pm 1.2$ \\
\hline E. coli $\mathrm{DH} 5 \alpha(\mathrm{pEPA} \Delta 1)[\mathrm{pGBM} 3:: \operatorname{sal}(\Delta v k t A)]$ & $34.0 \pm 0.7$ & $26.7 \pm 0.2$ & $24.1 \pm 1.2$ & $5.9 \pm 0.2$ & $9.2 \pm 1.7$ & $3.3 \pm 0.2$ \\
\hline
\end{tabular}

a The cells were grown at $20^{\circ} \mathrm{C}$ until the culture had an $\mathrm{OD}_{660}$ of 1.0

b Fatty acids are denoted as number of carbon atoms:number of double bond. The $\Delta$-position of double bond is presented in parenthesis

c Others include 12:0, 14:0, 18:0, and 3-hydroxyl 14:0

Table 2 Catalase activity of $E$. coli $\mathrm{DH} 5 \alpha$ and its various transformants

\begin{tabular}{lc}
\hline Strains $^{\mathrm{a}}$ & Catalase activity $\left(\mathrm{U} \mathrm{mg}^{\mathrm{p}}\right.$ protein \\
\end{tabular}

a Cells were washed three times with phosphate buffer $(\mathrm{pH} 7.5)$ by centrifugations at $3,000 \times g$ for 15 min, and they were then suspended in $0.2 \mathrm{ml}$ of $60 \mathrm{mM}$ potassium phosphate buffer (pH 7.0). Cells were disrupted by sonic oscillation using a Sonifier Cell Disruptor (model W185; Branson Ultrasonic Corp., Danbury, CT) for $40 \mathrm{~s}$ in an ice bath. Supernatants were removed after the centrifugation of cell lysates at $20,000 \times g$ for $60 \mathrm{~min}$ and were used as cell-free extracts

\section{Reference}

Okuyama H, Orikasa Y, Nishida T, Watanabe K, Morita N (2007) Bacterial genes responsible for the biosynthesis of eicosapentaenoic and docosahexaenoic acids and their heterologous expression. Appl Environ Microbiol 73:665-670 